$\left[\begin{array}{llr}\text { Jpn. J. Hosp. Pharm. } & \text { Pha } \\ \hline \text { 20(4) } & \begin{array}{c}\text { 般 } \\ 265-272\end{array} & (1994)\end{array}\right]$

寒天包埋活性炭ビーズの慢性呰不全治療用経口吸瓶剂

としての検討とクレメジンの評価 ${ }^{1}$

本田義輝, 中野真沉

熊本大学医学部附属病院薬剤部 $t^{2}$

\title{
Examination of Agar-Encapsulated Activated Carbon \\ Beads as an Oral Adsorbent for the Treatment of \\ Chronic Renal Failure and Evaluation of Kremezin $\dagger^{1}$
}

\author{
Yoshiteru HONDA, and MASAHIRO NAKANO \\ Department of Pharmacy, Kumamoto University Hospital† ${ }^{2}$
}

(Received September 28,1993$)$

(Accepted Junuary 27, 1994 )

Adsorption characteristics of creatinine by activated carbon beads consisting of about $67 \%$ activated carbon powder in ager were studied in vitro and compared with those of Kremezin ${ }^{\otimes}$ from the standpoint of usefulness for sequestering uremic wastes and uremic toxins exsorbed into the intestine. The extent and rate of creatinine adsorption on carbon in the beads were almost equal to those of the naked powder, and the preparation also demonstrated a similar adsorption behavior for creatinine as compared with Kremezin under the conditions of the presence of various ionic and nonionic additives. Furthermore, uremic peaks $2 a$ and $2 b$ on HPLC specific to chronic renal failure were readiy eliminated by the treatment of the beads in the uremic plasma. On the other hand, although the adsorption capacities of Kremezin for drugs were generally equal to those of medical carbon, the adsorption rate by Kremezin was smaller, but inferiority was not so serious as to make Kremezin useless as an oral antidote in acute intoxications brought on by drugs.

Keywords_ - activated carbon, activated carbon beads, activated charcoal, oral adsorbent, chronic renal failure, uremic toxins, uremic peaks, creatinine adsorption

\section{緒言}

消化管内には血中濃度に相関して種々の物質が

$\dagger^{1}$ 本報の内容は, 日本薬学会第113年会 (大阪, 1993 年 3 月）で発表した。本研究の一部は, 平成 3 年 度文部省科学研究費補助金 (奨励研究 (B)) によ口 た.

$\dagger^{2}$ 能本市本荘 1-1-1; 1-1-1, Honjo, Kumamoto, 860 Japan
存在するが, 腎不全患者においても例外ではな い1). 活性炭を経口投与して，消化管内で代謝性 老廃物や尿毒症性毒素を直接, または腸管壁を介 して吸着除去し，臨床的に腎不全進行の抑制就よ び透析導入時期の延長を意図する吸着療法 は, 1964年の Yatzidis らの試み坮まる. その後, 活性炭 ${ }^{3,4)}$ を心として，酸化デンプン5,6)，イオ. ン交換樹脂あるいはウレアーゼ等7)を用いて腎不 
全の保存的療法が種々検討されたが，長い間実用 化までには至らなかった。しかしながら，このた び石油系炭化水素由来の球形吸着炭“クレメジ ン”に尿毒症症状の改善効果が認められ, 臨床の 場に供されることとなった.

一方, 我々はこれまでに粉末活性炭の優れた吸 着能に着目し新しい経口投与用剂形の開発を目的 として, 粉末活性炭を寒天で包理することにより 顆粒状とした活性炭ビーズを試作し ${ }^{8)}$ ， 中毒解毒 剂9,10) 㧊よび高脂血症治療剂11)としての応用を検 討してきた。そこで今回，本製剤のクレメジン同 様の作用機作による慢性腎不全治療への応用性 を，尿毒症性物質の代表としてクレアチニンを対 象としてin vitroに打いて検討した。 また，クレ メジンの急性薬物中毒時の解毒剤としての適応を 想定して，いくつかの薬物に対するクレメジンの 吸着性についても検討した.

\section{実 験 の 部}

\section{1. 試料および試薬類}

活性炭は日本薬局方規格の薬用炭（犬日ノ出製 薬）を用い,クレメジンについては呉羽化学工業 より恵与されたクレメジンカプセル 200®を開封 して試料とした. クレアチニン, 牛血清アルブミ ン,トリオレイン, コール酸ナトリウム, テオフ

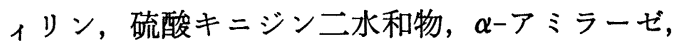
ペプシン,リパーゼ,トリプシンおよびキモトリプ シンは和光純薬工業の試薬を用いた。 またフコ ノバルビタール执よびアセトアミノフェンは，各 々丸石製薬および山之内製薬の局方品を用いた。 パラコートはアイ・シー・アイジャパン社（現： ゼネカ(侏) より提供を受けた。

寒天包理活性炭ビーズは， $4 \%$ 寒天（和光純薬 工業, 一級）水溶液中に粉末活性炭を $8 \%$ の割合 で分散させることにより得た球形ビーズを減圧乾 燥して調製した。詳細は先に報告した ${ }^{12) か ゙ ， そ の ~}$ 重量の $2 / 3$ が活性炭, 残り $1 / 3$ が寒天から成る顆 粒状製剤であり ${ }^{8)}$ ，今回の実験には調製できる主 分画である粒子径 297〜 590 $\mu \mathrm{m}$ (mesh size 28/ 48）の大きさのものを使用した。他の試薬はすべ て試薬特級を用いた。

\section{2. 吸满実験}

1）クレアチニンに対する吸着性

粉末活性炭およびクレメジンを各々約 $10 \mathrm{mg}$, 活性炭ビーズについては約 $15 \mathrm{mg}$ を正確に秤量 し, 各々 $50 \mathrm{ml}$ 用三角フラスコに入れ，精製水に て種々の濃度 $(200 \sim 1,000 \mu \mathrm{g} / \mathrm{ml})$ に調製したク レアチニン溶液 $10 \mathrm{ml}$ を加え, $37^{\circ} \mathrm{C}$ の恒温槽中 で24時間擋拌した. 擋挷停止後, $0.45 \mu \mathrm{m}$ のメン ブランフィルター (Minisart NML, Sartorius 社）でろ過することにより吸着剤を除去し，ろ液 中の遊離のクレアチニン濃度を Jaffé 反応を応用 した測定キット(クレアチニンーテストワコー, 和 光純薬工業）により定量した. 次に, 初期濃度と の差より吸着剂 $1 \mathrm{~g}$ 当たりの吸着クレアチニン量 を算出した。なお，飽和吸着量は吸着平衡状態に 拈けるクレアチニン濃度と吸着剤 $1 \mathrm{~g}$ 当たりの吸 着量との関係から, Langumuir の吸着等温式を 用いて算出した ${ }^{12)}$. 吸着速度の測定は, クレアチ ニン水溶液 $(1,000 \mu \mathrm{g} / \mathrm{ml}, 10 \mathrm{ml})$ に各吸着剂を 活性炭として $15 \mathrm{mg}$ ずつ添加して，72 時間まで 検討した。 また， $0.1 \mathrm{M} \mathrm{NaCl}, 0.1 \%$ テオフィリ ン, $2 \mathrm{mM}$ コール酸ナトリウム, $1 \%$ 牛血清アル ブミン (BSA) および $2.4 \mathrm{mM}$ トリオレイン存 在下で同様の実験を行らことにより, クレアチニ ン吸着に及ぼす共存物の影響を検討した。

\section{2）消化酵秦類に対する吸着性}

$\alpha-ア$ ミラーゼとペプシンは $37^{\circ} \mathrm{C}$, リペーゼ，キ

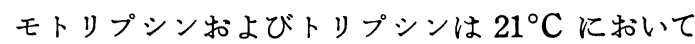
pH 7.4 リン酸塩緩衝液中で接触させることによ り, 粉末活性炭, 活性炭ビーズおよびクレメジン への吸着量を比較した。な括，酵素類の定量は， 紫外部での吸光度により行った.

\section{3）透析患者血泰中成分に対する吸着性}

正確に秤量した吸着剂を透析患者血漿に添加 し, $37^{\circ} \mathrm{C} 3$ 時間振と弓後, 遠心分離した. 上清 に対して, 小出らの高速液体クロマトグラフィー (HPLC) 分析 ${ }^{13)}$ を行い, クレアチニン, 尿酸お よび尿毒症性成分（ピーク $2 \mathrm{a}$ および $2 \mathrm{~b}$ ）に対す る吸着性を, 吸着操作前後の各ピーク面積により 検討した。 


\section{4）各種薬物に対する吸着性}

日本薬局方崩壊試験法に打ける第 1 液 $(\mathrm{pH}$

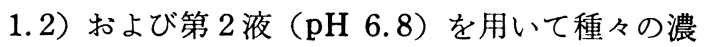
度に調製したテオフィリン,フェノバルビタール, キニジン，アセトアミノフェンおよびパラコート の各溶液に薬用炭（粉末活性炭）またはクレメジ ンを添加し，クレアチニンに対する吸着試験と同 様に行った。なお, 各薬物の定量は, 紫外部極大 吸収波長で直接吸光度を測定することにより行っ た。

\section{結果および考察}

\section{1. クレアチニンに対する吸着性}

慢性腎不全時の代表的な代謝性老廃物であるク レアチニンに対する粉末活性炭, 活性炭ビーズお よびクレメジンの吸着等温曲線を図 1 に示す. ク レアチニン濃度の上昇に伴い各活性炭製剂への吸 着量は增加し，ある一定濃度以上では吸着量は一 定値に近づき吸着飽和現象が確認された，活性炭 ビーズ, クレメジン共に粒形のため, 粉末活性炭 に比べ低い濃度では若干クレアチニンとの接触性 が劣るようにも見られたが，全般的には同様の吸 着挙動を示した。 またこれらのデータを基に Langumuir の式より飽和吸着量を算出すると, 各々, 粉末活性炭が $689 \mathrm{mg} / \mathrm{g}$, 活性炭ビーズが

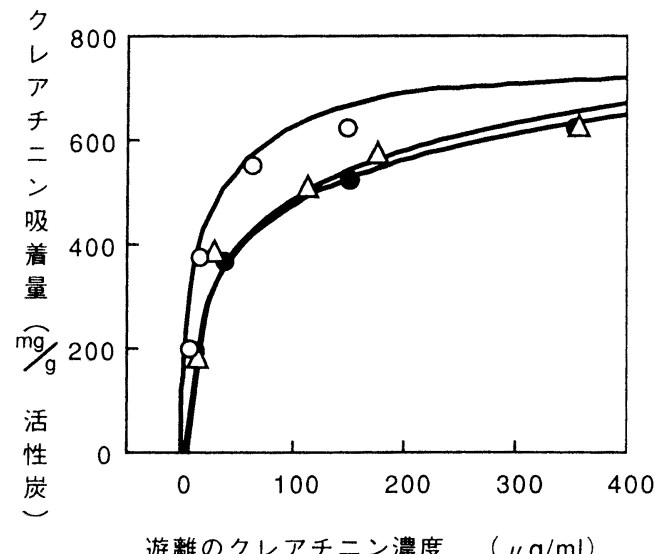

図 1. 粉末活性炭, 活性炭ビーズおよびクレメジ ンのクレアチニンに対する吸着等温曲線 ○, 粉末活性炭; ・, 活性炭ビーズ ; $\triangle$, クレメジン

活性炭として $671 \mathrm{mg} / \mathrm{g}$ 㧊よびクレメジンが 670 $\mathrm{mg} / \mathrm{g}$ と, 三者とも全く同等であった。 また，図 2 に水中でのクレアチニンの吸着速度を示すが, 三者とも同様のパターンであった. クレアチニン の活性炭製剂への吸着は, 一般的な薬物の吸着速 度に比べかなり遅い10) ものであり, 吸着平衡に達 するのには 2,3 日も要する.これは, クレアチ ニンが芳香環を持たない低分子であるために疎水 性が小さく，そのため活性炭への親和性が低いた
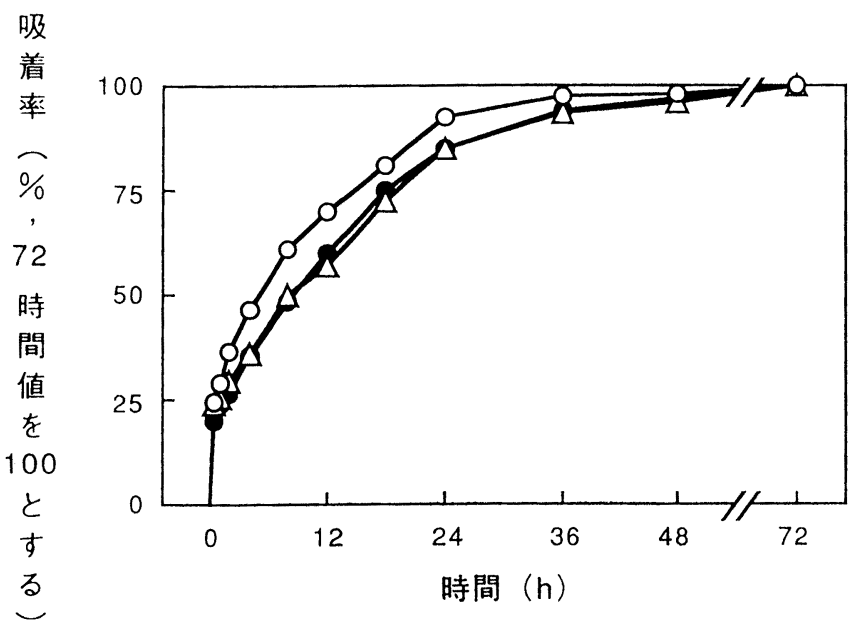

図 2. 粉末活性炭, 活性炭ビーズ执よびクレメジンのクレアチニン に対する吸着速度

○, 粉末活性炭 ; ○, 活性炭ビーズ; $\triangle$, クレメジン 


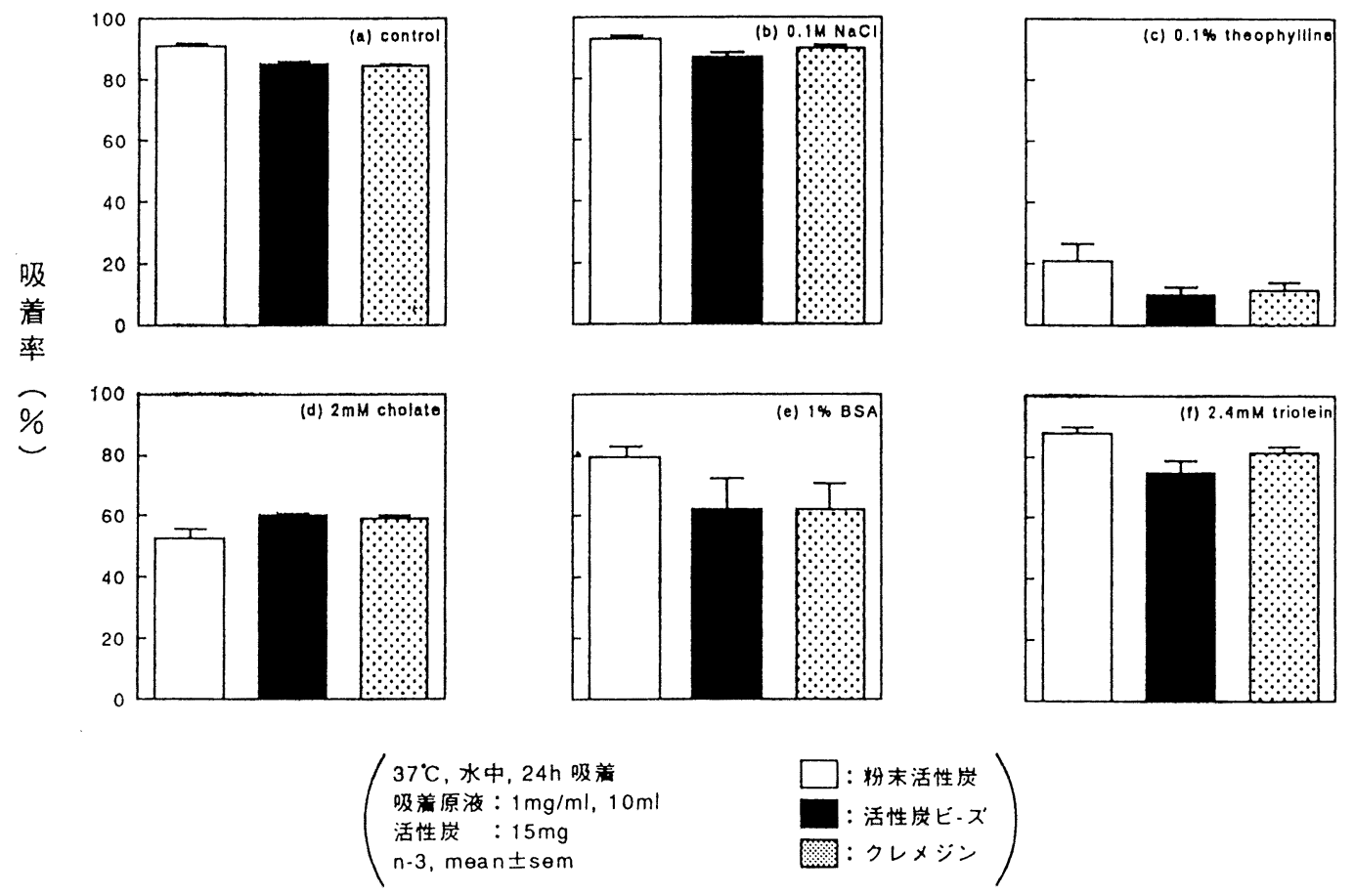

図 3. クレアチニン吸着に及ぼす共存物の影響

めと考えられる。

したがって，共存物の影響を受け易いことが予 想されたが，今回の検討結果を図 3 に示す。ま ず，無機塩類の例として $\mathrm{NaCl}$ を $0.1 \mathrm{M}$ の濃度 で添加すると, わずかではあるがクレアチニン吸 着量が増加する傾向が認められた。無機塩類共存 下で，その吸着能が損なわれるどころか逆に増大 するといら活性炭の特性は, 我々はこれまでにも 被吸着対象がサリチル酸 ${ }^{12)}$, コール酸 ${ }^{14)}$, キニジ ン9)扣よびパラコート15)の場合にも同様の結果を 得ており, 塩類による一種の塩析効果に基づくも のと推測された. また, 活性炭は, 通常, 薬物を その重量 $1 \mathrm{~g}$ 当たり数百 $\mathrm{mg}$ 吸着することが知ら れている16)が，その代表としてテオフィリンを $0.1 \%$ の濃度で共存する条件下においては, クレ アチニン吸着量は大きく減少しテオフィリンによ る強い競合的吸着阻害現象が認められた. クレア チニンに比ベテオフィリンの方が活性炭への親和 性が強く優先的に吸着されることが原因と考えら れる。
コール酸存在下に打いては, 粉末活性炭に比べ 活性炭ビーズ, クレメジンの方がクレアチニン吸 着量への影響は小さく, 逆に BSA 存在下では, 活性炭ビーズおよびクレメジンの方が強く阻害さ れる傾向にあった。 これは, 活性炭ビーズについ ては外側の寒天層の存在が, また, クレメジンに 関しては外表面の細孔のサイズ等が起因して，そ の結果として粉末活性炭と若干の差が生じたもの と考えられる.なお，中性脂肪のトリオレイン は，いずれの活性炭製剤においても大きな影響を 及ぼさなかった。

以上, 今回検討した 5 種類の共存物の影響は, 三者の活性炭製剤において大差は認められず，類 似の吸着阻害現象が確認された。したがって, 寒 天を用いて粉末炭を経口用のビーズ状としても吸 着能は損なわれることはなく，また，この製剤は 全くクレメジンと同等の吸着能, 吸着挙動を示し た、しかしながら，いずれの製剤においても，薬 物, 特に芳香環を持った疎水性の薬物が存在する と, 活性炭表面が薬物により優先的に占領され有 
効表面積が極端に小さくなることにより，クレア チニンを始めとする尿毒症性物質の吸着が大きく 損なわれ本来の治療効果を発揮し得ないことも危 惧され，臨床上十分注意すべき点と考えられる。 また，蛋白や胆汁酸類の吸着も考慮する必要があ ろう。

\section{2. 消化酵素類に対する吸着性}

代表的な消化酵素 5 種類の活性炭への吸着性を
表 1 に示す．粉末炭はいずれの消化酵素に対して も高い吸着力を示したのに対し，活性炭ビーズへ の吸着性は非常に低いものであった，消化酵素は 分子量数万の大きい分子であるために，寒天ゲル 内に進入し難いことが主な原因と考学られ，寒天 包理活性炭ビーズのこの性質は, 経口吸着剤とし て評価する際には消化酵素類による吸着阻害を受 け難いといら利点と考えられる。な牧，クレメジ

表 1. 消化酵素類に対する粉末活性炭, 活性炭ビーズおよびクレメジンの吸着性

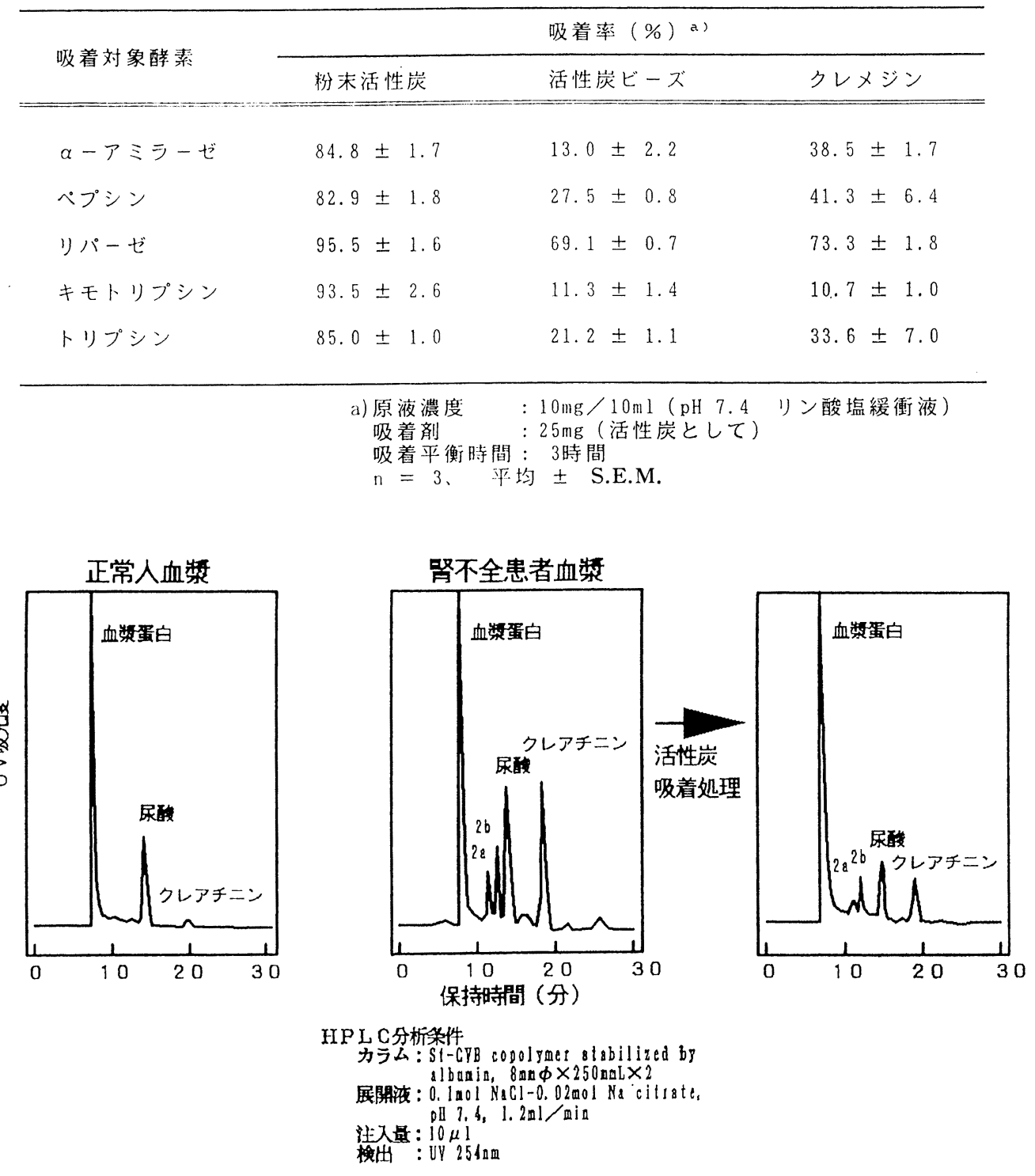

図 4. 活性炭吸着処理による HPLC 上尿毒症性ピーク $2 \mathrm{a}, 2 \mathrm{~b}$ および尿酸, クレアチニンピークの変化 
ンも同様に消化酵素に対しては弱い吸着力しか示 さなかった。

\section{3. 透析患者血墏中成分に対する吸著性}

図 4 に示すように，慢性腎不全患者の血漿を HPLC $^{13)}$ にて分析すると, 健常者に比ベクレアチ ニンや尿酸のピークが大きいばかりか，健常者で は見られない異常ピーク，つまり尿毒症性ピーク $2 \mathrm{a}$ 扩よび $2 \mathrm{~b}$ が特異的に検出される。 この透析患 者血漿に対し, in vitro に拈いて活性炭吸着処理 を施すと，いずれのピークも小さくなり，活性炭 による吸着除去が示唆された３種の吸着剂によ る除去率を表 2 に示す.

まず，尿毒症性ピーク $2 \mathrm{a} ， 2 \mathrm{~b}$ についは，ク レメジンはもちろん, 粉末活性炭および活性炭ビ 一ズでも吸着除去され得ることが確認された。 ま た，全般的に見てピーク $2 \mathrm{a} に$ に比べピーク $2 \mathrm{~b}$ 成 分の方が除去効率が良かった。
一方，尿酸，クレアチニンに対しても， 3 種の 吸着剤により血漿中より効率良く吸着除去が可能 であった。

\section{4. 各種薬物に対する吸着性}

テオフィリンに対する薬用炭（粉末活性炭）と クレメジンの吸着能を局方第 1 液および第 2 液中 で比較すると全く同程度であった（因 5 ). しかし ながら吸着速度に関しては，因6に示されるよう にクレメジンへの吸着は薬用炭に比べはるかに遅 い過程で進行し，吸着平衡に達する時間も薬用炭 では約30分であるのに対し，クレメジンでは 2 時 間程度も要した。これは, クレメジンが直径 0.2 $\sim 0.4 \mathrm{~mm}$ の粒形であるために, 内部の有効吸着 表面へ到達するのに多少時間がかかることに起因 すると考えられる.

中毒事故発生率の高い 5 種類の薬物を選択して 同様の吸着実験を行い，得られたデータより算出

表 2. 活性炭吸着処理による HPLC 上尿毒症性ピークおよび尿酸, クレアチニンピーク面積の変化 （a）尿毒症性ピーク2a、2bの残存ピーク面積（\%）

\begin{tabular}{|c|c|c|c|c|c|c|}
\hline \multirow{3}{*}{ 吸着剤 } & \multicolumn{6}{|c|}{ 活性炭添加量（g / dl) } \\
\hline & \multicolumn{2}{|c|}{0.5} & \multicolumn{2}{|c|}{1.0} & \multicolumn{2}{|c|}{2.5} \\
\hline & $2 \mathrm{a}$ & $2 b$ & $2 a$ & $2 b$ & $2 a$ & $2 b$ \\
\hline 粉末活性炭 & $87.6 \pm 4.8$ & $60.6 \pm 2.7$ & $58.7 \pm 2.2$ & $14.2 \pm 2.5$ & $39.7 \pm 3.9$ & $5.9 \pm 0.4$ \\
\hline 活性炭ビーズ & $99.1 \pm 6.3$ & $81.1 \pm 6.7$ & $74.9 \pm 6.0$ & $40.3 \pm 4.3$ & $51.3 \pm 4.0$ & $4.4 \pm 0.9$ \\
\hline クレメジン & $81.6 \pm 5.2$ & $46.6 \pm 5.6$ & $53.0 \pm 3.5$ & $8.8 \pm 3.0$ & $34.4 \pm 0.7$ & $6.3 \pm 0.9$ \\
\hline
\end{tabular}

（b）尿酸（UA） クレアチニン ( C r ) ピークの残存面積 (\%)

\begin{tabular}{|c|c|c|c|c|c|c|}
\hline \multirow{3}{*}{ 吸着剂 } & \multicolumn{6}{|c|}{ 活性炭添加量（g / dl) } \\
\hline & \multicolumn{2}{|c|}{0.5} & \multicolumn{2}{|c|}{1.0} & \multicolumn{2}{|c|}{2.5} \\
\hline & $\mathrm{UA}$ & $\mathrm{Cr}$ & UA & $\mathrm{Cr}$ & $U A$ & $\mathrm{Cr}$ \\
\hline 粉末活性炭 & $6.3 \pm 0.7$ & $25.4 \pm 2.3$ & N. D. & $6.4 \pm 0.3$ & N. D. & $1.5 \pm 0.4$ \\
\hline 活性炭ビーズ & $16.3 \pm 1.7$ & $38.5 \pm 2.1$ & $4.0 \pm 0.2$ & $14.2 \pm 1.9$ & N. D. & $3.6 \pm 0.5$ \\
\hline クレメジン & $7.6 \pm 1.8$ & $21.3 \pm 2.3$ & N.D. & $6.5 \pm 0.3$ & N. D. & $2.6 \pm 0.2$ \\
\hline
\end{tabular}


した飽和吸着量を表 3 に示す.クレメジンは粒状 であるにもかかわらず，一般的な薬物に対して粉 末炭と全く同等の吸着能を有することが確認さ れ, 粉末炭に代わる新しい中毒解毒剂としての応 用の可能性が示唆された.

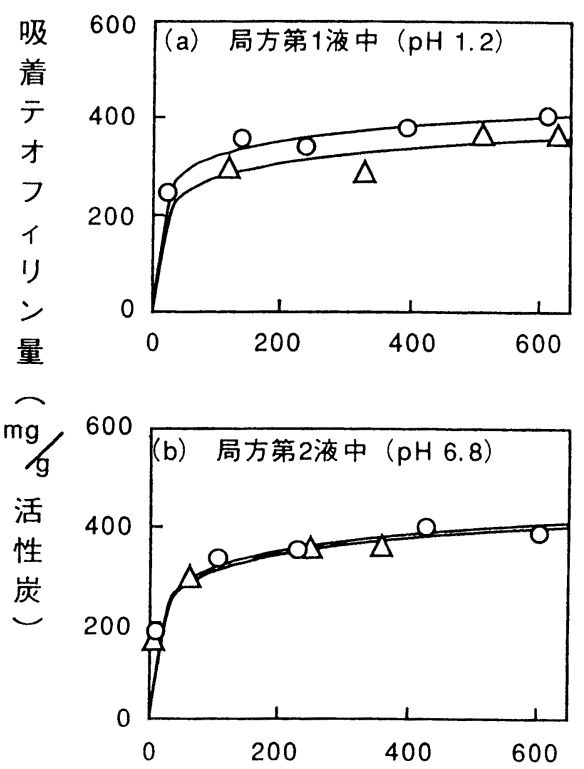

遊離のテオフィリン濃度 $(\mu \mathrm{g} / \mathrm{ml})$

困 5. 薬用炭(粉末活性炭) およびクレメジンの テオフィリンに対する吸着等温曲線

○, 薬用炭(粉末活性炭); $\triangle$, クレメジン

\section{5. 応 用}

透析患者 1 名の社会復帰に年間 500 万円以上の 医療費を要することを考慮すると，積極的な保存 的療法の必要性は, 今後益々高まることが予想さ れる.したがって，明確な透析導入遅延効果を持 つ経口吸着剤の開発および改良は緊急を要する社 会的課題と考えられる.市販品のクレメジンとの 比較により，我々の試作した寒天包理活性炭ビー

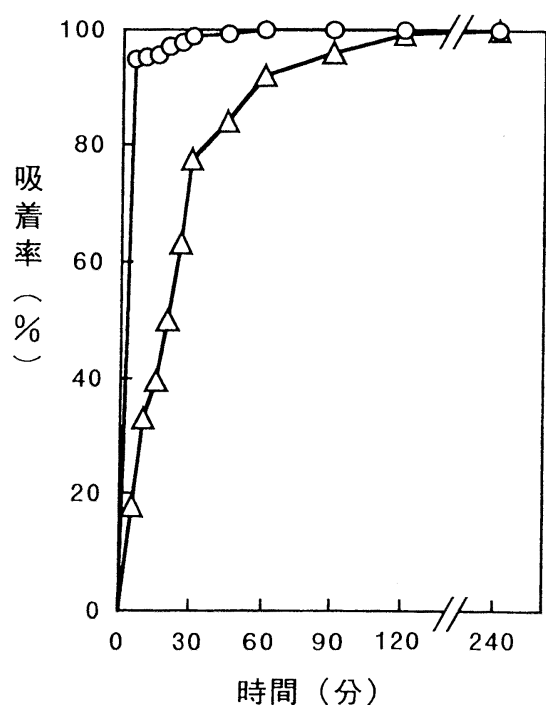

図 6. 薬用炭 (粉末活性炭) およびクレメジンの テオフィリンに対する吸着速度

○, 薬用炭(粉末活性炭); $\triangle$, クレメジン

表 3. 各種薬物に対する薬用炭およびクレメジンの飽和吸着量

\begin{tabular}{|c|c|c|c|c|}
\hline \multirow{2}{*}{ 澘 物 } & \multicolumn{2}{|c|}{ 局方第 1 液 [ $[\mathrm{pH}$ 1.2] } & \multicolumn{2}{|c|}{ 局方第 2 液〔 $[\mathrm{pH} \quad 6.8]$} \\
\hline & 蒕用岸 & クレメジン & 薬用炭 & クレメジン \\
\hline テオフィリン & 417 & $415(99 \%)$ & 397 & $365(92 \%)$ \\
\hline フェノバルビタール & 435 & $390(90 \%)$ & 363 & $348(.96 \%)$ \\
\hline キニジン & 114 & $104(91 \%)$ & 194 & $161(83 \%)$ \\
\hline アセトアミノフェン & 356 & $339(95 \%)$ & 352 & $352(100 \%)$ \\
\hline パシコート & 73 & $91(125 \%)$ & 83 & $96(116 \%)$ \\
\hline
\end{tabular}


ズにも慢性腎不全治療への応用性が示唆された. また，寒天に緩下作用があることから，活性炭ビ 一ズには活性炭の副作用である便秘を生じ難い利 点も期待される. 今回は, その活性炭原料として は犬日ノ出製薬の局方品を用いたが，活性炭はそ の原料扣よび製法（賦活法）により対象物質に対

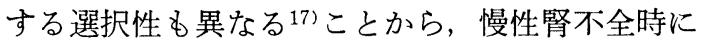
蓄積する代謝性老廃物や尿毒症性毒素の吸着に適 する活性炭原料のスクリーニングをさかのぼって 検討する必要もあろう.

他方, クレメジンの中毒治療分野への応用に関 して評価すると, クレメジンは造粒された球形炭 にもかかわらず，種々の薬物に対して通常の薬用 炭と比較しても遜色のない吸着能を有している. 現在, 中毒治療への適応を持つ活性炭製剂として は飛散性・付着性等の問題から取り扱い難く, し かも服用困難な薬用炭しかないことから判断する と, 中毒解毒薬としてもクレメジンは十分評価に 值する吸着剤であり, 臨床応用が期待されるとこ ろである。

謝辞 透析患者血漿の HPLC 分析にご協力いただ いた呉羽化学工業㧣医薬品部 中尾正明氏に謝意を表 します。

\section{引 用 文 献}

1) H. Yatzidis and D. Oreopolus, Kidney Int., 10, s-215-s-217 (1976).

2) H. Yatzidis, Nephron, 1, 310-312 (1964).

3) R.E.Sparks, N.S.Mason, P.M. Meier, M.H. Litt, and O.Linden, Trans. Am. Soc. Artif. Intern.Organs, 18, 458-464 (1972).

4) K. K. Goldenhersh, W. Huang, N.S. Mason, and R. E. Sparks, Kidney Int., 10, s-251-s-253 (1976).

5) R.E.Sparks, N.S. Mason, P. M. Meier, M.H. Litt, and O.Linden, Trans. Am. Soc. Artif. Intern.Organs, 17, 229-235 (1971).

6) T. Shimizu and S. Fujishige, J. Biomed.Mater. Res., 17, 597-612 (1983).

7) D. L.Gardner, R.D.Falb, B.C.Kim, and D. C. Emmerling, Trans. Am. Soc. Artif. Intern. Organs, 17, 239-245 (1971).

8) 本田義輝, 中野尚美, 中野臭汎, ファルマシア, 21, 414-417 (1985).

9）本田義輝, 岩奥玲子, 中野尚美, 中野異汎, 臨林 薬理, 15, 437-443 (1984).

10) Y.Honda, M.Nakano, and N.I.Nakano, $J$. Pharmacobio-Dyn., 13, 597-601 (1990).

11) Y.Honda, M. Nakano, and N.I. Nakano, J. Pharmacobio-Dyn., 10, 557-563 (1987).

12) N. I. Nakano, Y.Shimamori, M. Umehashi, and M. Nakano, Chem.Pharm.Bull., 32, 699707 (1984).

13）小出桂三, 遠山純子, 井上 帠, 越川昭三, 秋沢 忠男, 高橋 健, 日高三郎, 山根至二, 中尾正 明, 上原康夫, 西村 濞, 日腎誌, 28, 1101-1110 (1986).

14) N. I. Nakano, S. Funada, Y.Honda, and M. Nakano, Chem. Pharm. Bull., 32, 4096-4102 (1984).

15) 本田義輝, 中野尚美, 中野真汎, 病院菜学, 18, 100-105 (1992).

16) P. J. Neuvonen and K.T. Olkkola, Med. Toxicol., 3, 33-58 (1988).

17) N.I. Nakano, S. Funada, Y.Honda, and M. Nakano, Chem. Pharm. Bull., 33, 2084-2090 (1985). 